\author{
WIESEAW ŻARDECKI \\ ORCID 0000-0002-3856-4464 \\ Uniwersytet Marii Curie-Skłodowskiej \\ $w$ Lublinie
}

\title{
EDUKACJA OBYWATELSKA PRZEZ SZTUKĘ - ROLA TEATRU POLSKIEGO
}

\begin{abstract}
AвSTRACT. Żardecki Wiesław, Edukacja obywatelska przez sztuke - rola teatru polskiego [Civic Education through the Arts - the Role of Polish Theatre]. Studia Edukacyjne nr 60, 2021, Poznań 2021, pp. 161-175. Adam Mickiewicz University Press. ISSN 1233-6688. DOI: 10.14746/se.2021.60.9
\end{abstract}

The main purpose of this analytical paper was to highlight the ideas and phenomena in Polish theatre with regard to their role in civic education, and to determine the original qualities and peculiarities of this area of education through the arts. To that end, Fernand Braudel's the longue durée (long-term) perspective was adopted and a problematized approach to chronology was used as the principal research method, which allowed to present issues related to development and importance of this substantial trend in education through the arts, which due to its artistic and social importance surely deserves the most important place in the history of Polish theatre. What I construe as civic education theatre is theatrical realization (using a specific language) of a system of values promoting public-spiritedness (the raison d'etre of any human community) which is cultivated and enhanced by a given society and which impacts the spiritual life of its members. The analyses performed have shown that this prominent trend in the Polish drama and theatre, prevailing every now and then, and willingly used until this day, abounds in specific values of enormous importance embedded in the history of the Polish culture and the Polish spirit, created by outstanding artists; it is a legacy having no equivalent in other countries. Over the centuries, it has served as the foundation of the nation's spirituality, becoming the platform for civic political discourse, a symbol of the Polish cultural community, a means of transmitting historical tradition, a significant component of cultural identity, a substitute for social and political life, building self-knowledge and aspirations of a national community. Moreover, a concise review of historical traditions and peculiarities of civic values promoted by theatre in the Polish culture confirms the relationships between the arts and history of different nations, between Polish cultural tradition and our tragic history, between the nation's identity and human independence in personal and social terms. The analyses are performed in the spirit of education interpreted as a totality of values promoting and protecting public-spiritedness; regarding the examined theatrical trend as the major tradition in the history of Polish theatre; fundamental belief in the national and social function of the Polish theatre; consequently, understanding contemporary theatre as the outcome of the cooperation between progress and tradition. In view of the ongoing globalization and unification processes, awareness of the uniqueness of the major trend in the history of the national theatre and irreplaceable values Polish society may contribute to the multi-cultural European community appears to be one of the major challenges faced by Polish culture and education.

Key words: civic education, education through the arts, Polish theatre, theatrical tradition, civic education theatre 


\section{Wprowadzenie i idea wiodąca}

Nauki społeczne interesują się kulturą jako zespołem wartości wytworzonych przez niezliczone generacje w historycznym rozwoju, z których każda przede wszystkim dziedziczy dotychczasowy dorobek, a następnie wzbogaca go własnymi wytworami oraz zabiega, aby to co odziedziczyła i sama osiągnęła zostało przekazane kolejnym pokoleniom ${ }^{1}$. Każda epoka historyczna kształtuje pewien typ kultury materialnej i duchowej, system i hierarchię wartości, czy też ich zespoły, uświadamianych w postaci norm i wzorów kultury, które są ukonkretnieniem, „zmaterializowaniem” wartości, przy czym jedna wartość może wytwarzać kilka wzorów określających formy zachowań; niekiedy wzory mogą być konkurencyjne względem siebie. Wzory kulturowe ulegają zmianom, różnicują się, chociaż wartości pozostają niezmienne; jedne wzory zanikają, by pojawić się w późniejszym okresie, drugie ulegają pewnym modyfikacjom, inne po okresie ekspansji zostają zupełnie zdegradowane, jeszcze inne mają wartość ponadczasową, zajmują stałe miejsce w kulturze danej społeczności. Do tych ostatnich należą między innymi wzory kultury obywatelskiej i związane z nimi cechy, to jest pewne zespoły norm, modeli zachowań ludzkich, kryteriów oceny postępowania, które przenikają w głąb osobowości człowieka, kształtują pewną zamierzoną strukturę duchową i przyczyniają się do wzrostu pozytywnych zachowań obywatelskich, takich jak na przykład partycypacja społeczna i polityczna.

Zjawisko społeczne nazywane edukacją obywatelską dochodzi do skutku za przyczyną „,czegoś”, przez „,coś” jest powodowane i w „czymś” się wyraża oraz charakteryzuje określonymi właściwościami ze względu na cel, założenia, przebieg i funkcje, a także ze względu na ocenę skutków. Rozważając termin „obywatelskość”, Edward Shils podkreśla:

Obywatelskość to swoisty światopogląd i dyspozycja społeczeństwa obywatelskiego, wywodząca się z uczestnictwa jednostki w zbiorowej świadomości (...). Z obywatelskości wynika przywiązanie do całości społeczeństwa, objawiające się w decyzjach i działaniach zmierzających do ochrony i pomnażania dobra całego społeczeństwa ${ }^{2}$.

Edukacja obywatelska obejmuje te wszystkie działania, które w konsekwencji wspomagają rozwój człowieka otwartego na potrzeby społeczne i nastawionego na dobro wspólne oraz umiejętności społecznego działania, a jednocześnie nie tracą z oczu celu ogólnego - budowy społeczeństwa obywatelskiego opartego na zasadzie pomocniczości i solidarności społecznej³.

${ }^{1}$ Por. np. A. Kłoskowska, Encyklopedia kultury polskiej, tom 1 - Pojęcia i problemy wiedzy o kulturze, Warszawa 1991.

2 E. Shils, Co to jest społeczeństwo obywatelskie, [w:] Europa i społeczeństwo europejskie. Rozmowy $w$ Castel Gandolfo, przyg. i przedm. K. Michalski, Kraków 1994, s. 11.

${ }^{3}$ Por. np. A. Kordasiewicz, P. Sadura (red.), Edukacja obywatelska w dziataniu, Warszawa 2013. 
W realizacji edukacji obywatelskiej dzieła sztuki, czy szerzej - teksty kultury, dysponują bardzo różnymi i bogatymi możliwościami budowania przez człowieka własnej osobowości w duchu uznanych ideałów, zarówno w obszarach określanych mianem aktywności twórczej, jak i w procesach wartościowania, nadawania sensu oraz znaczeń, prowadzących do estetycznie i moralnie wzbogacających doświadczeń oraz działań. Edukacja obywatelska przez sztukę nawiązuje do dziedzictwa przeszłości (jako źródła wiedzy na temat wspólnych doświadczeń), ale urzeczywistnia się w teraźniejszości, a jej istotnym wymiarem jest ukierunkowanie na przyszłość, która stanowi istotną wartość, zobowiązanie do myślenia długoterminowego i alternatywnego.

Teatr, umownie nazwany przeze mnie teatrem edukacji obywatelskiej, może być rozumiany niejednoznacznie, a mianowicie jako tendencja, nurt, prąd teatralny lub też refleksja wyrażana $\mathrm{w}$ formie wizji artystycznej, manifestu, czy programu artystów teatru, będąca świadectwem kreowania sztuki scenicznej oraz zapisem doświadczeń pracy twórczej. Dla potrzeb niniejszego artykułu chciałbym przyjąć następujące znaczenie tego terminu: teatr edukacji obywatelskiej to ekspresyjne i przejmujące urzeczywistnienie sceniczne systemu wartości wspólnotowych, odpowiadających konkretnym potrzebom społecznym, jako inspiracja postaw patriotycznych i obywatelskich, zdolności do poświęcenia dla ojczyzny jako najwyższej formie życia społecznego i najwyższej wartości. Teatrem edukacji obywatelskiej określam zatem pewien system przekazywanych w ciągu dziejów znaczeń, zawartych w znakach i symbolach (takich jak ojczyzna, wolność, solidarność narodowa), a zarazem wpajanych nowym członkom określonej społeczności tak silnie, że są oni skłonni myśleć, wartościować i działać we właściwy dla dobra danego społeczeństwa sposób.

Artykuł, mający być przyczynkiem do określenia roli teatru polskiego w edukacji obywatelskiej dorosłej publiczności, składa się z dwóch części wzajemnie się dopełniających: 1) o tradycjach historycznych obywatelskiej roli teatru; 2) o oryginalnych swoistościach polskiego teatru odpowiedzialności obywatelskiej. Przyjmuje się przy tym, że wyzwolenie się z refleksji o teatrze w kategoriach istoty tej sztuki, jej odrębności, tworzywa, miejsca w kontekście innych sztuk i przejście na myślenie o funkcjach teatru w kulturze i życiu społecznym, jest obecnie znacznie potrzebniejsze niż rozważania w kategoriach estetyki, środków artystycznych, konwencji stylistycznych i tym podobnych. Zatem, teatr nie interesuje nas jako sztuka wyodrębniona spośród sztuk widowiskowych w ich historycznym rozwoju, ale jako czynnik kultury narodowej, w kulturze zanurzony i funkcjonujący w systemie życia duchowego swego narodu, wyrażający ogólnonarodowe dążenie, a jednocześnie interweniujący w najistotniejsze i najbardziej aktualne sprawy współczesności. Znane twierdzenie, że nie można zrozumieć współczesności teatru polskiego bez gruntownego poznania jego przeszłości, z której współczesność 
wyrasta, jest oczywiście truizmem, a jednak wciąż o tej niewątpliwej prawdzie zapominamy i usiłujemy teraźniejszość wyjaśnić bez uwzględnienia jej rozwojowego związku z poprzednimi epokami dziejów teatru, w przestrzeni „długiego trwania"4.

\section{Tradycje historyczne obywatelskiej roli teatru (dramatu)}

W niniejszym rozdziale wyróżnię niektóre okresy, zjawiska i dokonania teatru polskiego w obszarze edukacji obywatelskiej, czy też z nim związane, naturalnie pamiętając, że historia teatru jest ciągła, a poszczególne jego tendencje, nurty i prądy istnieją tylko w związku z innymi; i tylko w takich wzajemnych powiązaniach, uwarunkowaniach, zależnościach można ją zrozumieć. Początki polskiej literatury dramatycznej mają wyraźnie charakter edukacyjny, podstawowy cel, który jej stawiano, dotyczył przygotowania do życia obywatelskiego; tak było kiedy piętnowano współczesność za zanik patriotyzmu, upadek stanu rycerskiego, zamieranie ducha waleczności, lekceważenie spraw obronności. Jeszcze ostrzej rysuje się obywatelski charakter dramatu polskiego u jego narodzin w Odprawie posłów greckich Jana Kochanowskiego (1578), gdzie pedagogika społeczna wykracza poza cele naprawy obyczajów, sięga w sferę polityki i życia społecznego, podejmuje zagadnienie bytu narodowego zagrożonego partykularnymi interesami ${ }^{5}$. Z odległej perspektywy historycznej widać, że zainteresowanie teatrem jako narodową instytucją powołaną do publicznej służby rodziło się w Polsce w okresie renesansu, kiedy wychowawcza ideologia humanizmu w krajach Europy Zachodniej koncentrowała uwagę na zagadnieniach kształtowania osobowości poprzez kontakt z kulturą starożytną.

W oświeceniowym programie reform ustrojowych państwa, których realizację zaczęto uzależniać od świadomości obywateli, wzrasta misja teatru jako instytucji oddziaływania na opinię publiczną, narodowej szkoły dydaktyki społecznej (nie pozbawionej rozrywki), trybuny obywatelskiej dyskusji przenikniętej problematyką służby narodowej. Programowo stawia sobie za cel zwycięstwo obozu reform ustrojowych państwa komedia społeczno-obyczajowa i narodowo-polityczna: Franciszka Zabłockiego (1752-1821) i Juliana Ursyna Niemcewicza (1758- 1841), a przede wszystkim "ojca sceny narodowej” Wojciecha Bogusławskiego (1787-1866), który nazwał też teatr ",szkołą wychowania narodowego". Co najmniej trzy dramaty włączone w działania polityczne obozu reform należy tu przywołać: Powrót posła J.U. Niemcewicza (1791)

\footnotetext{
${ }^{4}$ F. Braudel, Historia i trwanie, przekł. B. Geremek, Warszawa 1999, s. 13.

${ }^{5}$ J. Lewański, Wstęp, [w:] Teatr polskiego renesansu. Antologia, oprac. J. Lewański, Warszawa 1988, s. 21.
} 
poprzedzający uchwalenie Konstytucji 3 Maja i agitujący na rzecz sił naprawczych państwa; Henryka VI na łowach W. Bogusławskiego (1792), który wszedł na scenę w okresie Targowicy, wzywał do ofiarnej miłości ojczyzny, potępiał stosunki w których „,intryga bierze górę, a zasługa upada”; Krakowiaków i górali (1794), gdzie W. Bogusławski przygotowywał duchową mobilizację mieszkańców Warszawy w przededniu wybuchu Powstania Kościuszkowskiego (1794). W tym miejscu można by przytoczyć jeszcze inne przykłady szczególnie silnego reagowania teatru oświeceniowego na doniosłe i dramatyczne wydarzenia z życia narodu, jakie poprzedziły ostatni rozbiór Polski 1795 roku: na Sejm Czteroletni 1788-1792 i ożywioną dyskusję polityczną z nim związaną, uchwalenie Konstytucji 3 Maja 1791, zryw Powstania Kościuszkowskiego w 1794 roku i na sławę, jaką zaczęła się cieszyć postać Naczelnika. Podsumowując epokę teatru niepodległej Rzeczypospolitej, należy stwierdzić, że wobec jawnego zagrożenia bytu samoistnego, pierwszy zawodowy teatr publiczny grający przedstawienia w języku polskim (1765) zyskał rangę jednej z ważniejszych instytucji edukacji obywatelskiej, emanującej postępowym programem reform, zawsze zabarwionym myślą narodową i patriotyczną.

Po utracie niepodległości cała w zasadzie sztuka polska w różnych swych przejawach odgrywa $w$ istocie trudną do przecenienia rolę przewodnią $w$ życiu duchowym narodu pozbawionego własnego państwa, walcząc o zachowanie własnej narodowej tożsamości i jednolitej wspólnoty kulturowej oraz przywrócenie niezawisłości państwowej. Może najdobitniejszym przykładem są tu arcydramaty polskiego romantyzmu Adama Mickiewicza (1798-1855), Juliusza Słowackiego (1809-1849) i Zygmunta Krasińskiego (1812-1859), które na całe pokolenia oddziaływały na szerokie kręgi społeczeństwa, kształtowały świadomość narodową i integrowały naród ponad granicami trzech imperiów oraz przygotowywały do walki o odzyskanie niepodległości. Przypomnieć warto, że romantyzm dokonuje wywyższenia narodu do godności najwyższego dobra na ziemi oraz formułuje tezę, że bez wspólnego języka, wspólnych dziejów i tradycji życia zbiorowego, wspólnych zasobów dóbr kulturalnych, wspólnego odniesienia do niektórych przynajmniej wartości nie może istnieć żadna grupa społeczna i tym bardziej żadna szersza spo-

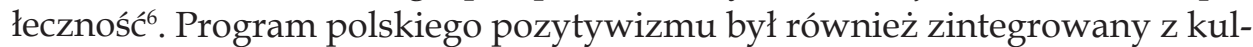
tywowaniem tradycji patriotycznych, zwłaszcza jako szansa przetrwania i ratowania polskości, w szczególności zachowania godności w warunkach niewoli, w obliczu poniesionej klęski Powstania Styczniowego (1863-1864), kiedy to teatr był jedynym miejscem (poza Kościołem), gdzie rozbrzmiewał język polski, usuwany stopniowo ze szkół i urzędów.

${ }^{6}$ G.I. Ihnatowicz, Naród, [w:] I. Ihnatowicz, A. Mączak, B. Zientara, J. Żarnowski, Społeczeństwo polskie od X do XX wieku, Warszawa 1988, s. 535-540. 
W okresie Młodej Polski sztuka, zwłaszcza sztuka dramatyczna, funkcjonuje już na wyżynach kultury polskiej jako swoistego rodzaju substytut życia społeczno-politycznego; pielęgnuje język i historię jako twierdze narodowości, utrwala polskie tradycje kulturowe, ukazuje narodowi jednolity los w warunkach rozbicia przez trzech zaborców. Głoszony przez Cypriana Kamila Norwida (1821-1883) jeszcze w połowie XIX wieku program stworzenia wielkiej sztuki narodowej opartej na tradycjach ludowych, pod koniec stulecia zyskuje ogromną popularność, między innymi w ludowych i narodowych pierwiastkach malarskiej dramatycznej twórczości Stanisława Wyspiańskiego (1869-1907), w szczytowym okresie Młodej Polski, która jednocześnie w nim przeżywała swe apogeum. Myśl teatralna największego artysty teatru w dziejach kultury polskiej, w tym nowocześnie pojętego dramatu narodowego, zbiega się z ideami wielkich reformatorów teatru (Edwarda Gordona Craiga, Adolpha Appii, Georga Fuchsa), wyprzedzając je nawet niekiedy, a później wykorzystują ją w swojej działalności inscenizatorskiej twórcy reformy teatru polskiego (Leon Schiller, Juliusz Osterwa, Wilam Horzyca i inni) ${ }^{7}$. Podsumowując ten fragment rozważań, należy dodać, że sztuce polskiej XIX wieku, rozwijającej się w trudnych warunkach politycznej niewoli, przypadł ważki udział w kształtowaniu świadomości narodowej; uczestnicząc w ogólnoeuropejskim nurcie przemian artystycznych zachowała ona swoją swoistość procesu rozwojowego, ambicje zmierzające do sprostania niewygasającym dążeniom niepodległościowym. Charakterystyczne dla tego okresu jest również zjawisko nieformalnego przywództwa, czy to w dziedzinie kultury czy polityki narodowej; rola, jaką w obrębie romantyzmu spełniali działający na emigracji poeci - wieszczowie i polityczni działacze: w ostatnim dwudziestoleciu przed pierwszą wojną światową rola polityczna, jaką spełniali ludzie tacy, jak Roman Dmowski i Józef Piłsudski ${ }^{8}$. Podkreślenia wart jest jeszcze fakt, że jednym $\mathrm{z}$ istotnych składników dziedzictwa okresu zaborów było uformowanie się oryginalnej i atrakcyjnej koncepcji narodu (bez własnego państwa) jako wspólnoty kultury, a także postawy obywatelskiej, głoszącej bezwarunkową wierność narodowi nawet za cenę utraty majątku czy kariery politycznej oraz gotowość do ofiary z życia w obronie ojczyzny ${ }^{9}$.

Dwudziestoletni okres odbudowy niepodległej państwowości (19181939) był z pewnością jednym z najciekawszych w dziejach kultury polskiej ze względu na unowocześnienie sztuki teatru i zainteresowanie problemami, którymi żyło społeczeństwo oraz wyznaczenie jej istotnej roli w życiu zbio-

\footnotetext{
${ }^{7}$ E. Miodyńska-Brooks (red.), Stanisław Wyspiański - studium artysty, Kraków 1996.

${ }^{8}$ S. Bednarek, B. Korzeniewski (red.), Polskie miejsca pamięci. Dzieje toposu wolności, Warszawa 2014.

${ }^{9}$ Por. A. Walicki, Trzy patriotyzmy: trzy tradycje polskiego patriotyzmu $i$ ich znaczenie wspótczesne, Warszawa 1991.
} 
rowym: kulturalnej integracji obszarów trójzaborowych. Wspólnym rysem twórczości teatralnej był zamiar stworzenia nowoczesnego języka teatru, który uczestnicząc $\mathrm{w}$ ogólnoeuropejskim nurcie przemian artystycznych miał być nie tylko kreatorem odradzającej się polskiej państwowości po 123 latach, ale także ambasadorem polskości wobec świata, jej ciągłości i trwania. W świetle badań historycznych teatrem, który wniósł liczący się wkład ideowo-artystyczny w rozwój polskiej sztuki scenicznej i kultury narodowej tego okresu był teatr monumentalny

realizujący największe dzieła polskiego dramatu (od czasów najdawniejszych do współczesności), które słowem poetyckim i kształtem inscenizacji o wielkiej sile oddziaływania wyrażały myśli, przeżycia i wartości istotne dla osobowości narodu ${ }^{10}$.

Równolegle rozwijała się prekursorska w skali światowej działalność malarza, dramaturga i filozofa Stanisława Ignacego Witkiewicza (1885-1939), inspiratora życia artystycznego, twórcy nieustannie poszukującego, autora oryginalnej teorii „,czystej formy”, która dała początek klasycznej awangardzie XX wieku; wywarła znaczący wpływ na kształt teatru powojennego ${ }^{11}$.

$\mathrm{W}$ drugiej połowie ubiegłego stulecia, $\mathrm{W}$ wyniku powojennych przeobrażeń politycznych i społecznych, kultura polska poddana została nowym ograniczeniom polityczno-ideologicznym, a specyficzną właściwością teatru polskiego pozostało znane z poprzednich okresów dążenie do łączenia przemian artystycznych $\mathrm{z}$ aspiracjami do przemian politycznych. W pojawiających się kreacjach świata przedstawianego odbijały się najnowsze losy naszego narodu, poszukiwanie uniwersalnego zasięgu wartości wspólnotowych, odwoływanie się do postaw moralnych niegdyś ukształtowanych, ale przydających się też jako inspiracja w naszych czasach. Teatr traktowany jako państwowa instytucja nobilitująca władzę ulegał kolejnym etapom przeobrażeń: daremnym próbom znalezienia wspólnej płaszczyzny poszukiwań artystycznych, sztucznego ujednolicenia form wypowiedzi, a w końcu gwałtownego rozszczepienia na szereg kierunków, nurtów i wyodrębnianych postaw poszczególnych artystów. Największy wpływ na rozwój teatru poszukującego miały bez wątpienia działania z pogranicza plastyki i teatru Tadeusza Kantora (1915-1990) i Józefa Szajny (1922-2008), a przede wszystkim koncepcje teatralno-kulturowe Jerzego Grotowskiego (1933-1999), oddziaływające rewolucyjnie oraz inspirująco na wiele obszarów współczesnej kultury i to w skali niemal całego globu ${ }^{12}$.

${ }^{10}$ B. Frankowska, Encyklopedia teatru polskiego, Warszawa 2003, s. 460.

11 Zob. T. Bocheński, Witkacy i reszta świata, Łódź 2011.

12 Zob. J. Słowiak, J. Cuesta, Jerzy Grotowski, Warszawa 2010; Z. Osiński, Jerzy Grotowski. Źródto, inspiracje, konteksty. Prace z lat 1999-2009, Gdańsk 2010. 
Zamykając powyższy krąg rozważań, przypomnijmy krótko zasadnicze fakty: dwa wieki życia narodu polskiego bez własnej państwowości i bez suwerennej państwowości to między innymi oddziaływanie poezji romantycznej i powieści historycznej; pracy organicznej i całego szeregu cennych, dziś zapomnianych inicjatyw społecznych, a także identyfikacja sztuki ze społeczeństwem w jego dążeniach patriotycznych; powstanie nowoczesnego narodu polskiego oraz poszukiwanie w sztuce innych źródeł prawdy o narodzie, niż urzędowe. Po dwustu latach od utraty niepodległości, wraz z przemianami ustrojowymi ostatniej dekady ubiegłego wieku, związanymi z etyką społeczną, demokratyzacją polityczną i rosnącą świadomością podmiotowości ze strony społeczeństwa obywatelskiego „musiała się zachwiać osobliwa monolityczność kultury organizowanej wokół wartości symbolizujących polską tożsamość"13. W ten sposób teatr polski mógł zapisać nowe karty swych dziejów, które były zarówno kontynuacją najlepszych dokonań artystycznych, jak i rozwinięciem "nowych idei przyspieszonej modernizacji” (określenie M. Janion), przez odrzucenie tradycyjnych wartości narodowych, a zwłaszcza dewaluację dziedzictwa romantyczno-symbolicznego, budującego poczucie tożsamości kulturowej. Brak jednak jeszcze odpowiedniej perspektywy pozwalającej określić aktualną kondycję teatru oraz obiektywnie ocenić, które ze zjawisk współczesnego życia teatralnego, rozwijającego się na wielu płaszczyznach, zajmą trwałe miejsce w naszym dorobku kulturalnym, zamanifestują prawdę naszych czasów w jego podstawowym nurcie życia narodowego.

Przytoczone w tej części artykułu tradycje i fakty - oraz wiele innych, tu pominiętych, może równie wymownych - są i mogą być świadectwem ciągłości oraz trwałości szczególnej funkcji (narzuconej przez historyczny los naro$\mathrm{du}$ ), jaką teatr spełniał $\mathrm{w}$ walce o duchowe przetrwanie narodu, zachowanie własnej narodowej tożsamości i jednolitej wspólnoty kulturowej; w walce rozgrywającej się w Polsce od końca XVIII wieku po transformację ustrojową lat 90. XX wieku.

\section{Oryginalne swoistości \\ i unikatowe osobliwości edukacji obywatelskiej przez teatr}

Analizując tradycje historyczne edukacji obywatelskiej przez teatr i próbując uchwycić jej tożsamość, musimy wydobyć elementy ciągłości i trwałości, a także odszukać głębszą kulturę wartości tkwiących w tej edukacji, kształtujących świadomość narodową, a wraz z nią poczucie odrębności

${ }^{13}$ M. Janion, Projekt krytyki fantazmatycznej. Szkice o egzystencjach ludzi i duchów, Warszawa 1991, s. 6. 
kulturowej. Kultura i teatr są ze sobą ściśle związane; teatr nigdy nie istniał poza kulturą i można nawet powiedzieć, że wykluczona jest ewentualność, by mógł on istnieć bez kultury; kultura wzbogaca teatr $w$ język i widzialne formy, poprzez które się on wyraża i porozumiewa z publicznością; z drugiej jednak strony to teatr ma wpływ na kulturę (np. Ateny przyznały teatrowi, centralne miejsce w kulturze antycznej). Zresztą, każda wielka kultura narodowa istniejąca we współczesnym świecie posiada bogatą tradycję teatralną z nią związaną; zatem nie jest możliwe zrozumienie określonej kultury bez zrozumienia teatru, który się za nią kryje: „(...) poznać jakąś kulturę znaczy poznać jej teatr - podkreśla Franco Ruffini - ale droga do poznania teatru wiedzie przez konteksty kultury"14.

Czy nakreślone tradycje edukacji obywatelskiej przez jeden z nurtów polskiego teatru dadzą się sprowadzić do wspólnego mianownika, czy można w nich odszukać wątki wspólne, trwałe niezmienniki, które wolno będzie określić mianem polskiego teatru dyskusji politycznej, troski obywatelskiej, patriotycznej odpowiedzialności za losy kraju? Zastanawiając się nad charakterystyką tego nurtu teatru polskiego, niełatwo naturalnie o uogólnienia, jednak narzuca się cecha zasadnicza, wynikająca z poczucia jego niewystarczalności, z konieczności przekraczania przez niego własnych ograniczeń, z wychylenia bardziej ku rzeczywistości, zwłaszcza rzeczywistości społeczno-politycznej, niż ku fikcji artystycznej. W świetle prowadzonych analiz teatr edukacji obywatelskiej jawi się jako instrument społecznego działania, środek negacji rzeczywistości zastanej i narzędzie interwencji politycznej człowieka oraz wyraz dążenia do zmiany istniejącego stanu rzeczy i do zainicjowania nowego procesu przekształcen; teatr ten chce tworzyć życie, przekształcać świat, budować przyszłość. Jest to cecha charakterystyczna polskiego teatru obywatelskiego zakorzeniona $\mathrm{w}$ tradycji życia duchowego narodu, jego dążenia do podmiotowości, samorządności; wynikająca z podporządkowania się koniecznościom, jakie nasze dzieje narzuciły sztuce, ale też prowadząca ku swoistej jego ułomności, ku powstawaniu czegoś, co można by nazwać teatrem nieteatralnym bądź nadteatralnym.

Doświadczenia życia duchowego narodu ukształtowały $\mathrm{w}$ nim pewien system wartości, z jednej strony mający wiele cech wspólnych z wartościami narodów zachodniego kręgu kulturowego, świadczących o ciągłości kultury polskiej i jej europejskich korzeniach, z drugiej zaś charakteryzujący się właściwościami odrębnymi i specyficznymi. Również recepcja importowanych, zachodnioeuropejskich form dramatycznych - zwłaszcza francuskich i włoskich - nie polegała na biernym przyswajaniu obcych zdobyczy; ulegały one $\mathrm{u}$ nas przekształceniom powodowanym $\mathrm{w}$ pierwszym rzędzie specyficznymi

${ }^{14}$ Pod. za: I. Sławińska, Teatr w refleksji wspótczesnej, Kraków 1990, s. 257. 
uwarunkowaniami narodowymi i politycznymi oraz ciążeniem dotychczasowej tradycji miejscowej ${ }^{15}$. Polski teatr miał - mimo otwartości na prądy artystyczne Europy Zachodniej - swoisty styl i koloryt, obecny niemal przez kilka wieków, od okresu stanisławowskiego, mocno nasyconego dydaktyzmem politycznym, a nawet „,złotego wieku” kultury polskiej, ze szczególnym spotęgowaniem żywotności w XIX wieku, a kończąc na okresie stanu wojennego i następującym po nim ostatnim okresie realnego socjalizmu. Jego ciąg rozwojowy tworzy pierwsza oryginalna polska tragedia renesansowa, moralna i polityczna, potem misja oświeceniowego teatru publicznego jako trybuny polityczno-obywatelskiej (aż do utraty niepodległości), a następnie arcydramat romantyczno-symboliczny i jego swoiste przedłużenie $w$ okresie modernizmu; wreszcie teatr monumentalny Drugiej Rzeczypospolitej, fundament kultury teatralnej w naszym kraju, budującej poczucie tożsamości narodowej i kulturowej. Od Odprawy postów greckich, poprzez Powrót posta, Krakowiaków i górali, a następnie Dziady, Kordiana, Fantazego, Samuela Zborowskiego, Nieboska Komedię, Irydiona, Wesele, Noc Listopadową, Wyzwolenie, Róże, Sułkowskiego, Termopile polskie, aż po Szewców, Ślub, Tango, Kartotekę ciągnie się ta linia dramatu wielkiej misji narodowej, polskich rozmyślań o wolności, ojczyźnie i niepodległości ${ }^{16}$.

Prestiż nurtu teatru obywatelsko-moralnego budowali wielcy twórcy naszej kultury (Kochanowski, Niemcewicz, Mickiewicz, Słowacki, Krasiński, Norwid, Wyspiański, Miciński, Żeromski, Gombrowicz, Mrożek, Różewicz i inni) oraz naszego teatru (Bogusławski, Wyspiański, Schiller, Osterwa, Horzyca, Swinarski, Grotowski i inni); budowali poprzez swoje dzieła, ale też projekty i wizje roli oraz miejsca teatru w życiu społecznym i politycznym oraz duchowym i religijnym; wizje które rozbudowywano w szczegółach i traktowano $\mathrm{z}$ taką powagą, jakby były już one bieżącą rzeczywistością ${ }^{17}$. Spośród wielu wybitnych osobowości artystycznych twórcami niemającymi sobie równych w omawianym nurcie teatru byli: Bogusławski, Wyspiański, Schiller, Grotowski i Kantor; ich działalność wytyczała szlaki odnowy teatru, wyrażała ogólnonarodowe dążenia oraz spajała polski i europejski sposób myślenia o sztuce.

W koncepcji i praktyce artystycznej nurtu teatru obywatelsko-moralnego rolę wartości nadrzędnych, decydujących o jego trwałości i ciągłości, pełniły wartości pozaartystyczne, społeczne i moralne, a zwłaszcza związane z dobrem wspólnym narodu i celami do których on dążył, natomiast estetyczne

15 Z. Raszewski, Krótka historia teatru polskiego, Warszawa 1990.

${ }^{16}$ Por. I. Sławińska, Rodzime tradycje w dramaturgii polskiej, [w:] Wkład Polaków do kultury świata, red. M.A. Krąpiec, P. Taras, J. Turowski, Lublin 1976, s. 605-618.

${ }^{17}$ E. Udalska, Wielkie utopie we wspótczesnym teatrze polskim. Kilka uwag wstępnych, [w:] Utopie w językach, literaturze i kulturze Stowian, tom 3, red. B. Tokarz, Katowice 1997, s. 105-118. 
walory formy teatralnej były wobec nich służebne i im podporządkowane. Nurt ten był swoistym zapisem losów dziejowych i przeobrażeń polskiego narodu, wyrazicielem jego dążeń i najwyższych ideałów, istotnym animatorem energii społecznej, swoistym nauczycielem patriotyzmu, trybuną względnie wolnej myśli, sumieniem oceniającym popełniane błędy, ale też źródłem nadziei i pokrzepienia w dramatycznych warunkach historycznych (wojny, zabory, powstania, prześladowania, ucisk cenzury, okupacja, transformacje itd.). W omawianym nurcie teatru zapisane jest

uniwersum polskości, na które składają się - jak to określa Jan Prokop - wszelkie znaki - symbole polskości: bohaterowie i wzory życia, wartości i normy, archetypy i toposy, mity i legendy, stereotypy i fantazmaty - wszystko to, z czego jesteśmy dumni, ale i to, co jest przedmiotem wstydu za "winy ojców” i własne słabości ${ }^{18}$.

Stawiając pytania zasadnicze dotyczące przyczyn utraty niepodległości, sensu cierpień narodu i przyszłego wyzwolenia, teatr ten rozwijał wyobraźnię historyczną, to jest pamięć i odczuwanie wspólnych losów dziejowych, budził sumienie i zbiorową świadomość oraz wzmacniał odrębność i tożsamość narodu jako kulturowej wspólnoty.

Analiza edukacji obywatelskiej przez teatr w aspekcie porównawczym wykazuje, że trudno znaleźć w Europie poza Polską tak silne powiązanie dziejów kultury, zwłaszcza teatru z historią narodu; innymi słowy - teatr odpowiedzialności obywatelskiej nie tylko wywodzi swój program z dążeń ogólnonarodowych, ale też jego świetność chronologicznie zbiega się z najbardziej ożywionymi dążeniami narodowymi. To właśnie nasze dramatyczne doświadczenia dziejowe i rozpamiętywanie przeszłości, by w ten sposób odnaleźć korzenie współczesności, najczęściej nadawały cel i sens twórczości dramatycznej i oddziaływały nie tylko na teksty teatralne, ale i na sposób ich przedstawiania, środki wyrazu artystycznego i odbioru społecznego. Można zatem dostrzec w nim wyjątkowo silną obecność problematyki politycznej wypływającej z konieczności reform ustrojowych państwa oraz narodowej, związanej z walką o suwerenność kraju, a potem o utrzymanie i odzyskanie niepodległości, z pewnym odsunięciem na drugi plan problemów ogólnoświatowo-poglądowych, które dominowały we Francji, czy estetycznych i religijnych, które z kolei nadawały ton życiu umysłowemu w Niemczech ${ }^{19}$. Charakteryzowany nurt należy traktować jako fundamentalnie ważny dla charakteru teatru polskiego, jako symboliczny skarbiec przesłań, wzniosłych wzorów, szczytnych idei, narodowych mitów oraz alegorii polskości, a także rezerwuar cytatów; jednocześnie jako oryginalny wkład w historię doktryn

${ }^{18}$ J. Prokop, Uniwersum polskie: Literatura, wyobraźnia zbiorowa, mity polityczne, Kraków 1993, s. 39.

${ }^{19}$ J.R. Brown (red.), Historia teatru, przekł. H. Bałtyn-Karpińska, Warszawa 1999. 
teatralnych oraz międzynarodowy ruch przemian i reform teatralnych minionych dwustu lat. W pierwiastku narodowym teatru obywatelsko-moralnego można upatrywać zarówno jego siłę, jak i słabość, ponieważ wnosi on inspirację do twórczości oraz nadaje jej niepowtarzalne i własne oblicze, ale jednocześnie czyni ją nieczy telną dla obcych odbiorców, utrudnia jej związek $\mathrm{z}$ teatrem światowym oraz zazwyczaj grozi utratą estetycznych walorów formy teatralnej.

Jakie będą dalsze dzieje teatru polskiego w ramach analizowanego kierunku, nurtu, prądu; czy będzie się go łączyć z poprzednimi okresami i traktować jako swoiste dopełnienie jego misji obrony tożsamości narodowej i kulturowej, tym razem wobec zagrożeń wynikających z procesów integracji i globalizacji kultury, czy też właśnie od tamtych okresów oddzielać - niełatwo naturalnie o odpowiedź. Zbyt blisko dziś jeszcze jesteśmy tego okresu, by można było się zdobyć na bardziej wyczerpujące uogólnienie zarówno jego jasno występujących dróg, jak i wartości trudniejszych do wydobycia i właściwej oceny, tym bardziej że nie stoi on pod znakiem przemożnego prądu umysłowego, nurtu ideowego, kierunku artystycznego - i jeszcze ich nie stworzył. Jak w każdym okresie przemian artystycznych występują w nim dwie sprzeczne tendencje: kurczowego trzymania się starych form wypowiedzi, doprowadzonych zresztą często do perfekcji, i poszukiwania nowych dróg, bardziej przystających do współczesnego odczuwania oraz odświeżających sztukę powiewem dotąd nieznanych lub dawno zapomnianych prądów. Wprawdzie można odnieść wrażenie wzajemnego wykluczania się tych dwóch tendencji, ale patrząc całościowo, zauważa się, że tendencje nowatorskie z jednej strony, a społeczne funkcje teatru $z$ drugiej nie tylko się wzajemnie nie wykluczają, lecz przeciwnie - uzupełniają, bowiem jedne wywołują drugie; aktywność z jednej strony pociąga za sobą aktywność w drugiej sferze.

W epoce jednoczenia się Europy oraz globalnego pojmowania kultury wielkim wyzwaniem dla polityki i edukacji jest waloryzacja naszego dziedzictwa kulturowego pod kątem wartości, które wzmacniają i wzbogacają naszą odrębność kulturową, narodową indywidualność, atrakcyjność dla innych narodów z jednej strony, z drugiej - rozumnie otwierają na nowe znaki kultury śródziemnomorskiej i stymulują myślenie w kategoriach wspólnoty europejskiej. Dążenia integracyjne sprowadzają się do lepszego wzajemnego porozumiewania się poprzez podobieństwo elementów kultury i sztuki poszczególnych narodów europejskich; większe zainteresowanie budzą jednak wartości osobliwe poszczególnych kultur, a z poznawania wzajemnych od- 
rębności kulturowych buduje się czasem porozumienie wprawdzie trudniejsze, ale głębsze i trwalsze ${ }^{20}$.

\section{Uwagi podsumowujące}

Głównym celem prowadzonych w niniejszym artykule analiz było ujęcie w całość syntetyczną problematyki rozwoju i odrębności edukacji obywatelskiej przez teatr polski w ten sposób, aby można było zaznaczyć jej najbardziej trwałe tradycje oraz wydobyć z niej te wartości, do których nawiązywano i które chroniono, i rozwijano. Przeprowadzone badania wykazały istotną zbieżność między ofertą edukacji obywatelskiej teatru polskiego, czyli zawartym $\mathrm{w}$ nim potencjałem wartości ukierunkowanych na wspólne dobro społeczności państwowej, a zapotrzebowaniem na edukację obywatelską społeczeństwa polskiego, to jest pobudzaniem partycypacji w życiu społeczno-politycznym. W ciągu wieków historii teatr polski, jego nurt odpowiedzialności obywatelskiej - jako najściślej społecznie uwarunkowany odzwierciedlał w sposób najbardziej bezpośredni charakter narodu w określonym czasie, istotne problemy polityczne, przeważające formy myślenia, panujące doktryny ideologiczne, typowe style życia, dominujące preferencje estetyczne. Równocześnie - jako interdyscyplinarna sztuka działająca synergicznie na publiczność - aktualizował tradycyjne wartości dziedzictwa kulturowego, stanowiące uniwersum kulturowe narodu oraz ujawniał elementy korelujące ze współczesnością, a także podstawowe antynomie egzystencji ludzkiej i konkretnego czasu historycznego, narodowo-społeczne problemy i konflikty.

Na podstawie zebranego materiału można stwierdzić, że w wymiarze społecznym omawiany nurt teatru polskiego powiązany był z życiem narodu wielorako: jako wyraz istotnych problemów politycznych, dokument ważnych wydarzeń historycznych, kuźnia patriotycznych postaw obywatelskich, instrument oddziaływania na opinię społeczną, manifestacja świadomości narodowej, substytut życia społecznego, forma egzystencji narodowej. Trudno znaleźć w Europie przykłady teatru bardziej niż polski teatr edukacji obywatelskiej związanego $\mathrm{z}$ historią narodu, poszukującego w przeszłości nie tylko skarbnicy wartości, ale także inspiracji, a jeszcze częściej może wyjaśnienia współczesności, a nawet ujawnienia związku między kulturą a losami historycznymi i charakterem narodowym. Narodowe dzieje polskiej sceny dostarczają dowodów, że znaczenie sztuki scenicznej określane było realizacją społecznych powinności, oporem przeciw publicznemu zniewoleniu, sku-

${ }^{20}$ A. Ziętek, Kultura w procesie globalizacji i integracji europejskiej, [w:] Wartości uniwersalne i odrębności narodowe tradycyjnych kultur europejskich, red. M. Marczuk, Lublin 2004, s. 24-33. 
tecznością pobudzania energii duchowej, stopniem zaangażowania w życie publiczne, żarem dyskusji problemów nurtujących społeczeństwo, powagą troski odpowiedzialności obywatelskiej za losy kraju. Problemy dotyczące rozumienia wolności jako celu działania, doświadczenie kolejnych prób jej odzyskiwania i metod jej przybliżania, a także poszukiwania odpowiedzi na pytania: czym jest wolność dla konkretnego pokolenia i jak dążenia do odzyskania (lub zachowania) wolności kształtują nasze aspiracje polityczne, kulturowe, społeczne - zachowują znaczenie dla kolejnych pokoleń21 ${ }^{21}$ Właśnie specyficzność i unikalność oraz osobliwość dziedzictwa polskiego teatru edukacji obywatelskiej może być uznana za źródło inspiracji twórczych oraz swoistych wartości i wzorów życia, tak indywidualnego jak i zbiorowego, a także istotny element kulturowych tradycji, w których wyrastały kolejne pokolenia i które stawały się częścią ich tożsamości i identyczności.

Zawarte w niniejszym artykule analizy nie dają pełnego obrazu teatru wielkiej misji narodowej; zabrakło autorowi miejsca na głębszą interpretację kluczowych zagadnień w szerszym kontekście i w układzie odniesienia do teatru europejskiego, jak również na wymienienie choćby twórców mniej znanych, niekiedy wręcz zapomnianych, zasługujących tu na przywołanie. Całość przedstawionych w tym artykule analiz, mimo niedoskonałości syntetycznego ujęcia, pozwala - jak sądzę - lepiej zrozumieć teatr polski w jego wymiarze edukacji obywatelskiej; nie daje natomiast odpowiedzi na pytanie, które wymaga żmudnych badań historyczno-pedagogicznych: czy teatr spełnił swe zadanie na miarę własnych możliwości i wymagań epoki. Nie wdając się w ryzykowne uogólnienia, można przyjąć, że siły naszego teatru w kulturze polskiej na przestrzeni dziejów określone były stopniem jego zaangażowania w życie społeczne i miarą jego udziału w programie edukacji narodowej, kształtowaniu postaw obywatelskich i utrwalaniu wartości ludzkich. Znaczenie teatru w edukacji obywatelskiej dorosłej publiczności należy mierzyć miarą bodaj najtrudniejszą - jego udziałem w naszych własnych poszukiwaniach samookreślenia wobec narodu - jego przeszłości, teraźniejszości i przyszłości - a także szczególnym wyczuleniem sumienia moralnego i świadomości etycznej, tak bardzo potrzebnym w nawiązaniu dialogu ze współczesnością.

\section{BIBLIOGRAFIA}

Bednarek S., Korzeniewski B. (red.), Polskie miejsca pamięci. Dzieje toposu wolności, Narodowe Centrum Kultury, Warszawa 2014. 2018.

${ }^{21}$ Por. np. P.T. Kwiatkowski, Odzyskanie niepodległości w polskiej pamięci zbiorowej, Warszawa 
Bocheński T., Witkacy i reszta świata, Wydawnictwo Officyna, Łódź 2010.

Braudel F., Historia i trwanie, przekł. B. Geremek, Wydawnictwo Czytelnik, Warszawa 1999.

Brown J.R. (red.), Historia teatru, przekł. H. Bałtyn-Karpińska, Wydawnictwo Diogenes, Warszawa 1999.

Frankowska B., Encyklopedia teatru polskiego, Wydawnictwo Naukowe PWN, Warszawa 2003.

Ihnatowicz I., Naród, [w:] I. Ihnatowicz, A. Mączka, B. Zientara, J. Żarnowski, Społeczeństwo polskie od X do XX wieku, Książka i Wiedza, Warszawa 1988.

Janion M., Projekt krytyki fantazmatycznej. Szkice o egzystencjach ludzi i duchów, Wydawnictwo Pen, Warszawa 1991.

Kłoskowska A. i in. (red.), Encyklopedia kultury polskiej XX wieku, tom 1 - Pojęcia i problemy wiedzy o kulturze, Instytut Kultury, Warszawa 1991.

Kordasiewicz A., Sadura P. (red.), Edukacja obywatelska w dziataniu, Wydawnictwo Naukowe Scholar, Warszawa 2013.

Kwiatkowski P.T., Odzyskanie niepodległości w polskiej pamięci zbiorowej, Narodowe Centrum Kultury, Warszawa 2018.

Lewański J., Wstęp, [w:] Teatr polskiego renesansu. Antologia, oprac. J. Lewański, Państwowy Instytut Wydawniczy, Warszawa 1988.

Miodyńska-Brooks E. (red.), Stanistaw Wyspiański - studium artysty, Wydawnictwo Universitas, Kraków1996.

Osiński Z., Jerzy Grotowski. Źródło, inspiracje, konteksty. Prace z lat 1999-2009, Wydawnictwo słowo/obraz terytoria, Gdańsk 2010.

Prokop J., Uniwersum polskie: Literatura, wyobraźnia zbiorowa, mity polityczne, Wydawnictwo Universitas, Kraków 1993.

Raszewski Z., Krótka historia teatru polskiego, Państwowy Instytut Wydawniczy, Warszawa 1990.

Shils E., Co to jest społeczeństwo obywatelskie, [w:] Europa i społeczeństwo europejskie. Rozmowy $w$ Castel Gandolfo, przyg. i przedm. K. Michalski, Wydawnictwo Znak, Kraków1994.

Sławińska I., Rodzime tradycje w dramaturgii polskiej, [w:] Wkład Polaków do kultury świata, red. M.A. Krąpiec, P. Taras, J. Turowski, Wydawnictwo Towarzystwa Naukowego KUL, Lublin 1976.

Sławińska J., Teatr w refleksji współczesnej, Wydawnictwo Literackie, Kraków 1990.

Słowiak J., Cuesta J., Jerzy Grotowski, Wydawnictwa Uniwersytetu Warszawskiego, Warszawa 2010.

Udalska E., Wielkie utopie we wspótczesnym teatrze polskim. Kilka uwag wstępnych, [w:] Utopie w jezykach, literaturze i kulturze Stowian, tom 3, red. B. Tokarz, Wydawnictwo Uniwersytetu Śląskiego, Katowice 1997.

Walicki A., Trzy patriotyzmy: trzy tradycje polskiego patriotyzmu i ich znaczenie wspótczesne, Wydawnictwo Res Publica, Warszawa 1991.

Ziętek A., Kultura w procesie globalizacji i integracji europejskiej, [w:] Wartości uniwersalne i odrębności narodowe tradycyjnych kultur europejskich, red. M. Marczuk, Wydawnictwo UMCS, Lublin 2004. 